This is a draft chapter. The final version is available in S. Kumlin and I. Stadelmann-Steffen: How Welfare States Shape the Democratic Public: Policy Feedback, Participation, Voting and Attitudes, Edward Elgar, pp. 223-243. http://dx.doi.org/10.4337/9781782545491.00020

The material cannot be used for any other purpose without further permission of the publisher, and is for private use only.

\title{
Raising the retirement age: retrenchment, feedback and attitudes
}

\section{Elias Naumann}

\section{INTRODUCTION}

Life expectancy in western societies is increasing. A man of pensionable age living in an OECD country is expected to live, on average, a further 18.5 years - compared to 16.2 years 20 years ago (OECD 2011). With increasing life expectancy people spend more time in retirement, provided the retirement age remains unchanged. As ageing populations challenge the sustainability of the pension system, an increase in the retirement age seems to be an inevitable reform alternative (OECD 2011). This step is however frequently met with great resistance. In this chapter I examine if and how attitudes towards increasing the retirement age have changed in recent years. Is the opposition to reform crumbling with rising reform pressures? And what are the effects of a reform that changes the legal retirement age? Moreover, do groups within societies react to these developments differently, and do we thus find increasing conflicts, for 
example between social classes? Or can we perhaps observe the emergence of new conflict lines, for example between the old and the young?

This chapter contributes to two key aspects of the general framework of this book. First, an analysis of aggregate public opinion on the country level is combined with an examination of how specific groups of individuals react to particular policy reforms. Second, I aim to complement the rather static findings of previous attitudinal research focusing on cross-country comparisons at a single point in time (Boeri et al. 2002; Fernández and Jaime-Castillo 2013 for studies on pension attitudes) or on changes over time in single-country studies (Litwin et al. 2009) with a more dynamic analysis of reform preferences over time and across different institutional settings in order to infer whether and to what extent welfare state reforms influence citizens' attitudes.

Using data from 25 European countries between 2004 and 2009 I provide an indepth examination of the dynamics at both the country and the individual levels regarding attitudes towards increasing the retirement age. Using multilevel analysis I am able to link the macro- and micro-levels of explanation. Since some countries increased their legal retirement age during this period it is possible to assess the causal effect of reforms on attitudes using a quasi-experimental design (difference-indifferences). Due to data availability - repeated cross-sectional data and not panel data on the individual level - this strict test of causality will only be possible for the aggregate level.

This chapter is organized as follows. I begin with a discussion of the main theoretical expectations regarding the relationship between national-level pressures and policies and how they affect attitudes towards increasing the retirement age. Before 
presenting data, methods and results I provide a short summary of recent pension policy trends across Europe.

\section{THEORY AND PREVIOUS FINDINGS}

\section{The Interrelationship between Policy and Public Opinion Over Time}

The question of how public opinion and policies are linked is now a prominent and widely researched topic in the social sciences. Theoretical and empirical research support the claim that it is, in fact, an interrelationship: opinion affects policy (Brooks and Manza 2006; Page and Shapiro 1983) and policy affects opinion (Burstein 2003; Mettler and Soss 2004; Pierson 1993). In this chapter I am interested in the policyopinion nexus - how feedback processes of policies impact opinion. How do people adapt their preferences (e.g. in terms of retirement age) to a policy change (e.g. a reform raising the retirement age)?

Theoretically, absolute and relative preferences have to be distinguished from one another. Absolute preferences refer to the optimal level of policy, e.g. which exact retirement age people prefer. It is questionable whether people indeed have these absolute preferences, since policy is often far too complex for individuals to prefer a specific policy level independent of the current policy. Relative preferences, however, capture individual policy opinions much more reliably, as people are better able to state their preferred level of policy in comparison to the current policy. In line with previous 
research (e.g. Soroka and Wlezien 2009) I therefore refer to relative preferences if not otherwise stated.

Two explanations for the policy-opinion link exist in the literature. Proponents of a negative feedback claim that 'in effect, the public would behave like a thermostat; when the actual policy "temperature" differs from the preferred policy temperature, the public would send a signal to adjust policy accordingly, and once sufficiently adjusted, the signal would stop' (Wlezien 1995, p. 981). Thus, an increase of the retirement age decreases the preference for further increasing the retirement age as the demand for a higher retirement age is satisfied to some extent by the policy change. Soroka and Wlezien (2009) confirm this expectation in their extensive account of the development of individual attitudes (preferences for spending in different policy areas) and spending in the US, Canada and the UK from the early 1980s to the early 2000s. In the US an upward shift of one standard deviation in spending on welfare leads to a downward shift in preferences in the following year of an average 26 percentage points. Similar results have been found for Canada and the UK and also hold across subdomains of the welfare state. Adapting this argument to preferences for the retirement age, I propose the following hypothesis:

\section{H 1: $\quad$ Saturation hypothesis}

In countries that raise the retirement age the preference for further increasing the retirement age decreases. Countries with a high retirement age will thus exhibit lower levels of acceptance for further increasing the retirement age. 
In contrast, policy may feed back positively on preferences (Baumgartner and Jones 2002). According to this argument an increase of the retirement age will result in an increased preference for further raising the retirement age. Two explanations support this argument. The first is concerned with the positive consequences of a policy change: If people experience positive consequences from a policy change they may want to have 'more of the same', assuming that further policy changes in the same direction will have further positive effects. The second explanation for positive feedback effects claims that people adjust their absolute preferences in reaction to a policy change. Under the assumption that 'policies, once established, act as institutions, because they create a framework in which certain resources, rules and norms are imposed upon citizens' (Lowi 1964, p. 644), this argument is consistent with institutional theory. While institutions do not directly affect the strategic calculus of actors, they do shape basic preferences and the very identity of individuals (Hall and Taylor 1996).

In line with these arguments, Raven et al. (2011) find a positive effect of old-age pension expenditures on preferences for more spending in the following year. High pension expenditures led to an increased preference for spending in the Netherlands between 1970-2004. A major limitation of previous research is its narrow focus on spending preferences. As expenditure changes, particularly in pensions, are usually the result of policy decisions from the distant past, these studies have difficulties explaining attitudes as a result of current reforms. Comparing Germany (where the so-called 'Riester reform' took place in $2001^{1}$ ) and Italy (where no reform took place), Boeri et al. (2002) examine the direct effect of a reform on public attitudes. Their results show that the reform increased awareness of the untenability of the pension system. Reducing public benefits led to an increasing acceptance of lower taxes and reduced benefits. 
They conclude that 'the Riester reform seems to have backfired' (Boeri et al. 2002). Following the positive policy feedback argument I propose the following alternative hypothesis.

\section{H 2: $\quad$ Alignment hypothesis}

In countries where the retirement age has been raised, the preference to further raise the retirement age increases. Countries with a high retirement age will show high levels of acceptance for further increases of the retirement age.

\section{Policy Effects on Group Differences in Attitudes}

Even if the overall level of acceptance has not changed, the pattern of attitudes may have nevertheless changed. For example, some groups in society might increase their acceptance of increasing the retirement age, whereas others may oppose such a reform even more strongly. Therefore, my focus now turns to the pattern of attitudes and where conflicts are located within societies, and whether policy changes affect these group differences in attitudes. As already mentioned, the available data on the individual level do not allow a strict causal test of the effects of raising the retirement age for different groups. Therefore the 'era of permanent austerity', culminating in the 2008 global financial crises, serves as the background against which changes in the attitude structure are examined. The emergence and expansion of the welfare state is generally understood as a struggle or negotiation between social groups with differing interests. This struggle takes place in and is thus shaped by the inequality and opportunity structure of a respective society (Esping-Andersen 1990). One of the most prominent 
theories in welfare state research building on this idea is the power resource theory. The two main types of power resources are the control over capital and the control over labour. 'In Western societies variations in the difference in power resources between labour and business interests can be expected to have a variety of consequences. This difference can influence [amongst others] the level and patterns of conflicts in the society' (Korpi 1983, p. 80). The power resource theory (Korpi 1983) thus claims that welfare state support is guided by class interests. Accordingly, Boeri et al. (2002) find a positive relationship between social class and the acceptance of raising the retirement age, with higher classes being more favourable to increases in the retirement age. Findings are however inconclusive when looking at respondents' left-right selfplacement as further indicator of old cleavages. Whereas Fernández and Jaime-Castillo (2013) and Litwin et al. (2009) provide evidence that people with a right political ideology are more in favour of increasing the retirement age, other studies (Lynch and Myrskylä 2009; Boeri et al. 2002) find no significant effect of political ideology.

\section{H 3: $\quad$ Old cleavages hypothesis}

The preference to increase the retirement age should be structured along class and left/right ideological lines.

Several general trends in the development of modern societies are often said to contribute to declining class cleavages (Clark and Lipset 2001): for example, the development towards a risk society (Beck 1992), individualization trends and the transition to a postmaterialist, postmodern or postindustrial society (Inglehart 1990). First risk society (Beck 1992) and individualization-hypotheses claim that the issues 
social policies address, such as unemployment, lack of health care or poverty in old age, are understood as individual risks, and protection against them is a matter of individual responsibility, not the responsibility of social groups or governments. These changes are likely to create a society where class loses its saliency as a base for identities and interests. Second, the basic idea behind post-materialism (Inglehart 1990) is that the traditional motivations of material and social security have lost their effects on behaviour and attitudes. Traditional hierarchies are declining and stratification based class has become fragmented. As with the conclusions reached for the risk society, class cleavages are declining in importance.

\section{H 4: $\quad$ End of class politics hypothesis}

The association between class and preferences to increase the retirement age will decline over time, resulting in minor or no class differences in the pattern of preferences.

The 'new politics of the welfare state' literature (Pierson 2001) analyses welfare state change against a backdrop of increasing pressures and austerity, and assumes attitudes to depend on the interests of groups benefitting from certain social policy programmes. It is claimed that interest formation in times of welfare state retrenchment follows a quite different logic compared to times of welfare state expansion. As long as the welfare state was expanding, reforms basically aimed at redistributing additional benefits. Even if benefits were not distributed equally and interests were conflicted, this conflict is assumed to be less pronounced, as people usually agree with a reform if they benefit in some way. In contrast, in times of austerity reform is about retrenchment or at 
least recalibrating the welfare state. Opposition to such reforms is assumed to be much stronger. Conflict lines should run between groups who benefit from the welfare state, thus defending 'their' programmes, and the net payers who are more inclined to accept reforms and cutbacks. Conflict (and opposition to reform) might be even more severe if additional benefits for some groups or social policy programmes are only possible at the cost of other groups or social policy programmes.

In terms of ageing societies, the emerging conflicts between generations have not only gained attention in the media but also among scholars, and are often assumed to comprise the most important new cleavage in the field of pension policy. Current pensioners are expected to favour an increase of the retirement age since this stabilizes the level of current and future pension payments without any costs for the retirees. Among the working population, younger employees are expected to be more supportive than older employees. Younger employees have a higher life expectancy, thereby reducing the relative costs of working longer. They would benefit more from a stabilization of contribution rates, as they still have more contribution years to pay. In line with these expectations, previous research frequently finds a U-shaped relationship, with younger and older respondents favouring an increase of the retirement age and middle-aged workers opposing it (Fernández and Jaime-Castillo 2013).

Gender is another new cleavage. Women are expected to support the welfare state more than men since they are more likely to rely on the welfare state as widows or single parents. They are also more likely to be employed by the welfare state. Existing differences in the life expectancy and the legal retirement ages between men and women possibly add to this conflict. Moreover, as recent reforms of the retirement age 
have tended to align women's with men's legal retirement age, women are more affected by reforms (Fernández and Jaime-Castillo 2013; Velladics et al. 2006).

Furthermore, three arguments suggest that an increase of the retirement age is more acceptable for higher educated people. First, they usually have a better capability to work longer, as their jobs are less physically demanding. Second, the marginal utility of additional contribution years is possibly higher for the better educated, as they started to work later in their lives and have not yet paid in as many years as the less educated. Third, higher educated people tend to be better informed about the effects of the demographic change and should thus have a greater awareness of the reform pressures (Boeri et al. 2002).

H 5: $\quad$ New cleavages hypothesis

New group differences in the preference to increase the retirement age based on narrow self-interest will emerge or (if already there) increase.

PENSION SYSTEMS UNDER PRESSURE: PENSION POLICY TRENDS ACROSS EUROPE

This chapter analyses changes of reform preferences against the backdrop of increasing reform pressures, continued restructuring and retrenchment. The following summary of social and economic trends related to the pension system and how governments reacted to these changes should locate the time period examined in this chapter within the general socio-economic development over the last 25 years. 
Rapidly ageing populations due to increasing life expectancy and low fertility rates pose a major challenge to the sustainability of pension systems and increases reform pressures (OECD 2011). In the 25 EU countries the dependency ratio increased on average from 22.4 per cent in 2004 to 23.7 per cent in 2009. Moreover general economic trends and the financial crisis of 2008 placed additional pressures on financing pension systems. In reacting to these changes, countries have a variety of policy alternatives at their disposal. For the period between 1990 and 2005, Soede and Vrooman (2008, p. 23) identify the following typical measures:

- Providing more funded schemes or greater reliance on funded schemes.

- Promoting private schemes.

- Reducing benefits.

- Promoting longer employment.

- Raising the retirement age and closing the gap in retirement age between men and women.

These measures are partly reflected in the institutional characteristics of the $25 \mathrm{EU}$ countries included in this analysis. The promotion of private schemes possibly led to a slight decrease from 90.1 per cent to 89.8 per cent in terms of the public share of total expenditures on old age, survivor and incapacity benefits. As the replacement rate remained stable, efforts to reduce benefits did not show any consequences at the EU level. The promotion of longer employment is reflected in an increase of the average effective retirement age. Of specific interest for this study is the last policy measure suggested by Soede and Vrooman (2008), raising the legal retirement age. Seven of the 
25 EU countries decided to change the retirement age from 2004 to 2009 (Table 11.1). ${ }^{2}$

Whereas the Czech Republic and Slovakia implemented these reforms immediately, Austria, Denmark, Germany, Italy and the UK postponed the implementation for four to 18 years.

Table 11.1 Legislated reforms of the statutory retirement age between 2004 and 2009

\begin{tabular}{lcccc}
\hline $\begin{array}{l}\text { Countries which } \\
\text { increased the } \\
\text { retirement age }\end{array}$ & .. for men & .. for women & Legislation & Implementation \\
\hline Austria & 60 to 65 & 56.5 to 60 & 2005 & $2017-2033$ \\
Czech Republic & 62 to 65 & 60 to 63 & 2008 & $2008-2030$ \\
Denmark & 65 to 67 & 65 to 67 & 2006 & $2024-2027$ \\
Germany & 65 to 67 & 65 to 67 & 2007 & $2012-2029$ \\
Italy & 57 to 65 & 57 to 60 & 2004 & $2008-2014$ \\
Slovakia & 60 to 62 & 57 to 62 & 2004 & $2004-2014$ \\
UK & 65 & 60 to 65 & 2007 & $2010-2020$ \\
\hline
\end{tabular}

Sources: European Commission (2011b), Fultz (2006), Hirose (2011).

\section{DATA AND MEASUREMENT}

Data for this study is taken from the Eurobarometer, a biannual survey with representative samples of the population aged 15 years and over residing in each of the member states. On the basis of the availability of the dependent variable, I chose Eurobarometer surveys 62.1, 64.2, 66.3 and 71.3, which were conducted in 2004, 2005, 2006 and 2009, respectively. The data provides information on 99,233 individuals from 25 EU countries. Country samples vary between 500 and 1,561 respondents per year and were weighted for sex, age, region and size of locality.

The preference for increasing the retirement age is measured by the following item: 
If you had to choose from the following possibilities aimed at guaranteeing the financing of the pension system in (OUR COUNTRY), which one would be most acceptable for you? ${ }^{3}$

Responses included 'Work and contribute for longer', 'Maintain the retirement age and increase your social security contributions' and 'Maintain the current retirement age and accept that you will receive less'. Some respondents answered spontaneously 'None of these' or 'A combination of all three'. These answers were recorded separately.

Compared to measuring preferences using open questions (e.g. EB56.1: 'Do you agree that the age of retirement should be raised so that people work longer and therefore spend less time in retirement?'), the question used here has the advantage that it poses a realistic trade-off between specific policy options. As my main interest in this study is the attitude towards an increase in the retirement age, I recoded answers into a dummy variable. Respondents who answered that it would be most acceptable to work and contribute for longer are assumed to favour an increase in retirement age over the other alternatives. All other respondents favour other policy alternatives and are assumed to oppose an increase in the retirement age. ${ }^{4}$

\section{Independent Variables at the Country Level}

Until recently the standard approach to explaining country differences in welfare attitudes has been to draw on Esping-Andersen's (1990) regime types (e.g. Arts and Gelissen 2001). Since such a strict categorization of welfare systems to single types might obscure real changes, a more promising approach is to use specific indicators of the pension system, thereby allowing us to capture gradual institutional changes. The most visible policy change is an increase of the legal retirement age. These reforms are 
fiercely debated and are usually accompanied by public protests and strikes. Since the legal retirement age for men and women differs in some countries I include the average of the legal retirement age of men and women. Some countries have extensive opportunities for early retirement and the legal retirement age does not really affect people's decision to retire (Ebbinghaus 2008). To capture current retirement practices I include the average effective retirement age. In order to get an unbiased estimate of the effect of a reform raising the retirement age, it is necessary to control for other simultaneous changes which could also affect attitudes. To account for country differences in demographic and economic development, I draw on the dependency ratio $^{5}$ as an indicator for pension specific reform pressures and the unemployment rate as an indicator for general reform pressures. I use the aggregate replacement rate ${ }^{6}$ to capture the institutional context of the countries' pension systems as an indicator for the generosity of the pension system.

\section{Independent Variables at the Individual Level}

Social class and political ideology represent old cleavages. To operationalize social class I use the European Socio-Economic Classification (ESeC) and classified respondents according to occupation (see Rose and Harrison 2007). The salariat (e.g. lawyers, scientists, engineers) is distinguished from intermediate employees (e.g. office clerks, government officials), from small employers and the self-employed, and from the working class (e.g. care workers, tool makers, cleaners). The unemployed, pensioners and disabled were assigned the class score that referred to their last occupation; respondents who have never worked are added as an additional category. People's political orientation was operationalized by their self-placement on a ten point 
left-right scale. Answers were collapsed into three categories: Left (1-4), right (7-10) and centre $(5,6)$ as the reference category.

As proxies representing different degrees of self-interest age, age squared, gender and education are taken as the most important new cleavages. A respondent's education is assessed using the age at which he or she exited full-time education, distinguishing between primary or no education, secondary education and tertiary education. Family status (whether married or not) and household size are included as additional controls.

\section{RESULTS}

\section{The Feedback Effect of Raising the Retirement Age}

I start with a descriptive analysis of the trends over time. Figure 11.1 provides a graphical illustration of country differences after controlling for compositional effects. Countries are ordered from left to right according to their level of support in 2004. Examining the variation over time, a prominent finding is that the acceptance 'to work and contribute for longer' increased on average across the EU between 2004 and 2009. In 200419 per cent of the EU25 population found it most acceptable to work and contribute longer, compared to 24 per cent in 2009. This trend becomes even more remarkable when the results of previous studies from the early 2000s are added. They usually found an increase of the retirement age to be opposed by a majority of the respondents, with only 14 per cent of the population accepting this reform alternative 
(Velladics et al. 2006) Over the same time period pressures to reform increased due to ageing populations and the financial crisis. It therefore seems as if people reacted to these changes by abandoning their aversion to increasing the retirement age. Of course such correlational evidence does not establish causality. The main focus of this section is exactly to gain some insights into the direction of causality. Therefore, I focus on one reform alternative and examine more specifically how a policy change increasing the retirement age affects the acceptance to work and contribute longer. 


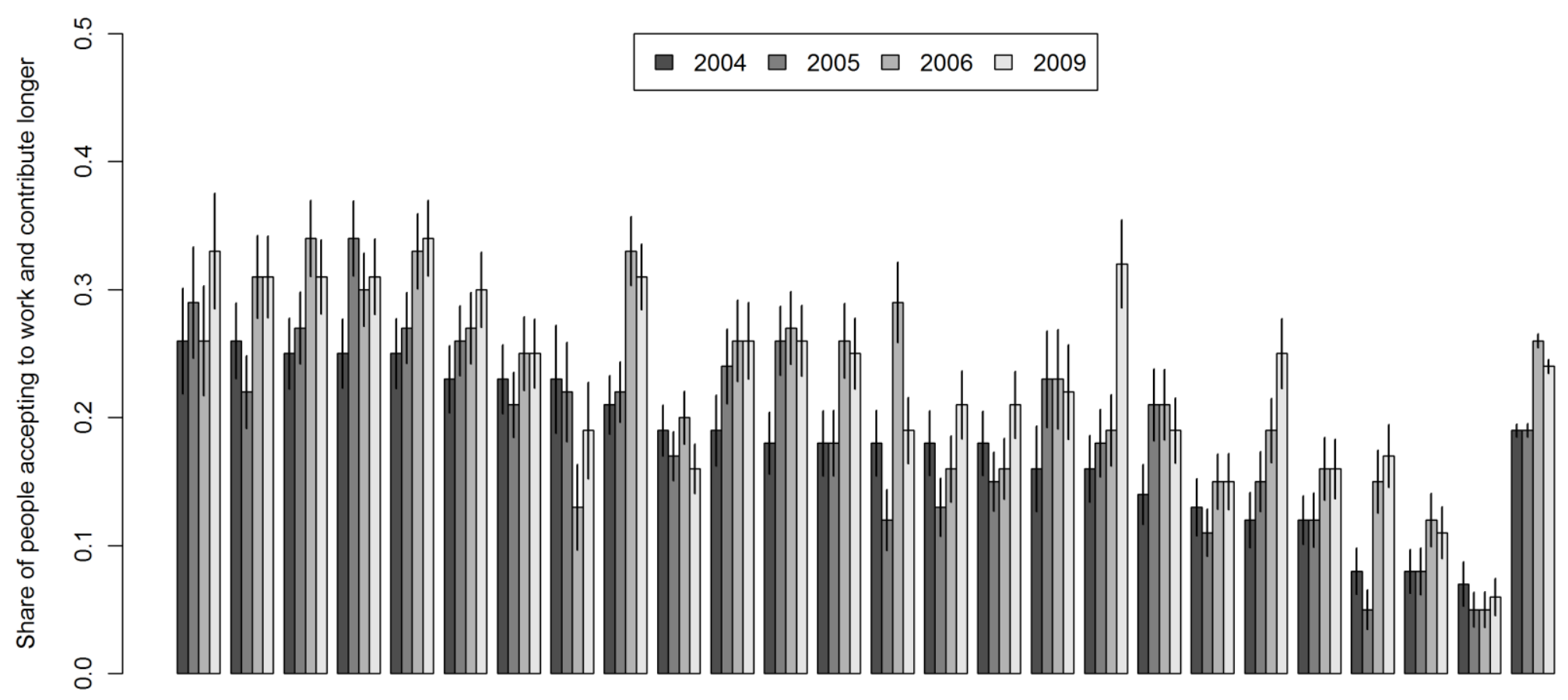

MT PL FR DK Fi BE SE CY GB DE IE NE IT ES EE LV LU PO LT CZ AT SK HU SI GR EU

Note: MT Malta, PL Poland, FR France, DK Denmark, Fi Finland, BE Belgium, SE Sweden, CY Cyprus, GB Great Britain, DE Germany, IE Ireland, NE Netherlands, IT Italy, ES Spain, EE Estonia, LV Latvia, LU Luxembourg, PO Portugal, LT Lithuania, CZ Czech Republic, AT Austria, SK Slovakia, HU Hungary, SI Slovenia, GR Greece, EU European Union ( 25 countries).

Figure 11.1 Estimated support and 95\% confidence intervals for all 25 countries and the EU average 
As seven of the 25 countries in the sample changed the legal retirement age between 2004 and 2009, I am able to estimate the causal effect of this reform using a 'differencein-differences' approach (DID) (Angrist and Pischke 2009). The basic idea of the difference-in-differences method is to mimic an experimental design. In a true experimental design we would need both a random assignment of the reform to a group of countries and a control group of countries without a reform. Ideally we would observe both groups before and after the treatment is applied and then watch how each group changed at the time of the treatment. And this is exactly the idea of the DID approach: examining how the differences between treatment and control group outcomes change before and after the treatment. ${ }^{7}$ For example, Italy and Slovakia rose their statutory retirement age in 2004. For this first available period the attitude change from 2004 to 2005 in Italy and Slovakia (the treatment group) is compared with the general trend, that is, with the average attitude change in all other countries where no reform took place (control group). This strategy is then repeated for the subsequent periods. Including countries without a reform as a counterfactual control for unobserved heterogeneity and period effects. All unobserved determinants that affect every country in the same way are thus barred as potential explanations for the attitude change. The crucial assumption of the DID approach is that nothing else has changed at the same time of the treatment (the reform). In most instances this assumption is too strong and not met in reality. To account for these potential confounding simultaneous changes, additional control variables are included. Table 11.2 shows how the acceptance of increasing the retirement age, that is, the share of people favouring an increase of the retirement age, changes from one year to the next as a result of changes in the independent variables. 
Table 11.2 Effect of a reform of the legal retirement age on the acceptance to work and contribute longer. Difference-in-differences estimation with standard errors clustered on the country level; 25 EU countries, yearly changes in the period 2004-2009

\begin{tabular}{|c|c|}
\hline & $\begin{array}{l}\text { Change in the acceptance to } \\
\text { work and contribute longer }\end{array}$ \\
\hline Reform of the legal retirement age & $-3.38^{+}$ \\
\hline$\Delta$ Effective retirement age & 0.57 \\
\hline$\Delta$ Dependency ratio & 0.49 \\
\hline$\Delta$ Unemployment rate & 0.02 \\
\hline$\Delta$ Replacement rate & -0.05 \\
\hline 2004 & ref. \\
\hline 2005 & 0.72 \\
\hline 2006 & $3.99 *$ \\
\hline 2009 & $5.20^{*}$ \\
\hline$N$ & 100 \\
\hline$R^{2}$ within & 0.39 \\
\hline rho & 0.79 \\
\hline
\end{tabular}

Note: $+\mathrm{p}<0.10, * \mathrm{p}<0.05$.

First, looking at the year dummies the previous findings regarding the overall trend are confirmed. Compared to 2004 the level of acceptance of increasing the retirement age is constant in 2005, but then significantly increases by 3.99 percentage points in 2006 and by another 1.2 percentage points in 2009 (period effects). With regard to the reform effect, if the legal retirement age increases by one year, the overall acceptance of its increase in a given country decreases by 3.38 percentage points. Controlling for changes of other important institutional characteristics of the pension system and for period effects, I can rule out that these characteristics or the general time trend account for the effect. ${ }^{8}$ Thus, with regard to the direct short-term effects of a pension reform, the saturation hypothesis is confirmed. After the legal retirement age has been raised, acceptance of a further increase drops. 
In this analysis I take the year of the legislation as the time of a reform, thereby assuming that this is the more relevant stage in the reform process where we should expect to observe feedback effects. There is usually a general discussion preceding or following the legislation; people are thus aware of the reform and possibly even know which party is accountable for the reform. Nevertheless, since most reforms postpone their implementation by up to 20 years (Table 11.1), the effect of a reform might be larger if it is in place and 'felt' by citizens (cf. Lindbom's findings on the difference between retrenchment proposals and binding decisions, Chapter 8 in this volume). As Lindbom's main argument refers to the transparency of reforms I would still argue that in the case of reforms, increasing the retirement age the time of implementation is much less transparent to the wider public than the time of legislation, as only a very small share of people is actually affected, that is, the cohort retiring in this year. Moreover, at the implementation stage a potential feedback effect can be assumed to be comparably small since the retirement age usually changes gradually, increasing the retirement age step-wise by, for example, two months per year.

\section{The Stability of Old and New Cleavages}

The aggregate level of acceptance and the structure of individual attitudes within a country are independent of each other. While the overall level of acceptance might increase, the structure of attitudes remains unchanged if all individuals or social groups increase their acceptance in parallel. The focus now turns to the pattern of attitudes and the question where conflicts are located within societies and how they develop over time. As the unit of analysis changes from the country to the individual, I rely on crosssectional data at four points in time rather than time-series data. I am therefore unable to 
provide a strict test of the causal effect of a reform on individual attitudes. As an alternative the development of mounting reform pressures, retrenchment and restructuring outlined above is taken as a background against which changes in the attitude structures are examined.

In order to test the hypothesis on whether the impact of social class has decreased and been replaced by new emerging cleavages, I use the following analytical strategy. I start by estimating separate multilevel models for each year including first the old cleavage variables (social class and political ideology) and then the new cleavage variables (age, gender and education). The first model, where only the old cleavages are included, examines whether old cleavages remain relevant in structuring attitudes. The inclusion of new cleavages into the model provides us with some insights as to whether new cleavages are also salient determinants of the attitude structure. Moreover, a decrease of the old cleavage coefficients after the inclusion of the new cleavages would indicate that new cleavages supersede old cleavages. In a final step I compare the four full models across time in order to detect changes in the attitude structure.

In line with the theoretical expectations I find significant differences between the social classes (Table 11.3). ${ }^{9}$ The odds for a member of the highest social class to accept working and contributing longer is 1.29 times higher than the odds for a member of the working classes (in 2004). With regard to political ideology, people with a right political ideology are more in favour of an increase in the retirement age, whereas people with a left political ideology tend to oppose such a reform. Consistent with previous studies on class and welfare attitudes (Naumann forthcoming; Svallfors 2006) these old cleavages do not lose their significance and only slightly decrease in magnitude after the inclusion of the new cleavages. In no year do we see any evidence 
for the hypothesis that new cleavages are supplanting old cleavages. As both seem to be important determinants of the attitude structure, I will now turn to the full models with both old and new cleavages.

Most of the differences are in the expected direction and are rather stable over time (Table 11.3). As mentioned above, the upper social classes and people with a right political ideology have the highest acceptance of increasing the retirement age. As for the new cleavages, age, gender and education, I observe a rather stable U-shaped age effect: The youngest and the oldest favour an increase of the retirement age, whereas the working-age population (25 to 64) opposes an increase in the retirement age. There is a strong and significant gender effect, with men being more supportive of an increase of the retirement age than women. Moreover, raising the retirement age is more acceptable to those with tertiary education than for those with secondary or primary education. This might be the result of their awareness of the reform pressures, but can perhaps be traced back to a greater capability to work longer. Both reasons make this reform alternative more attractive for the more educated. 
Table 11.3 Group differences in the acceptance to work and contribute for longer: Results of a multilevel-logit regression-Odds ratios [Standard errors in brackets]

\begin{tabular}{|c|c|c|c|c|}
\hline & $\begin{array}{c}(1) \\
2004\end{array}$ & $\begin{array}{c}(2) \\
2005\end{array}$ & $\begin{array}{c}(3) \\
2006\end{array}$ & $\begin{array}{c}(4) \\
2009\end{array}$ \\
\hline \multicolumn{5}{|l|}{ Old cleavages: } \\
\hline The working class & ref. & ref. & ref. & ref. \\
\hline - The salariat & $\begin{array}{l}1.29 * * \\
{[0.08]}\end{array}$ & $\begin{array}{l}1.38^{* *} \\
{[0.08]}\end{array}$ & $\begin{array}{l}1.25^{* *} \\
{[0.07]}\end{array}$ & $\begin{array}{l}1.25^{* *} \\
{[0.07]}\end{array}$ \\
\hline - Intermediate employees & $\begin{array}{l}1.19 * * \\
{[0.08]}\end{array}$ & $\begin{array}{c}1.04 \\
{[0.07]}\end{array}$ & $\begin{array}{c}1.12 \\
{[0.07]}\end{array}$ & $\begin{array}{l}1.14^{*} \\
{[0.07]}\end{array}$ \\
\hline $\begin{array}{l}\text { - Small employers and self- } \\
\text { employed }\end{array}$ & $\begin{array}{l}1.24^{*} \\
{[0.11]}\end{array}$ & $\begin{array}{l}1.29 * * \\
{[0.12]}\end{array}$ & $\begin{array}{l}1.34^{* *} \\
{[0.11]}\end{array}$ & $\begin{array}{l}1.19^{*} \\
{[0.10]}\end{array}$ \\
\hline - Never worked & $\begin{array}{c}1.13 \\
{[0.14]}\end{array}$ & $\begin{array}{c}1.25 \\
{[0.16]}\end{array}$ & $\begin{array}{c}1.17 \\
{[0.14]}\end{array}$ & $\begin{array}{l}1.42^{* *} \\
{[0.18]}\end{array}$ \\
\hline Centre & ref. & ref. & ref. & ref. \\
\hline - Left & $\begin{array}{l}0.89 * \\
{[0.05]}\end{array}$ & $\begin{array}{c}0.92 \\
{[0.05]}\end{array}$ & $\begin{array}{l}0.88^{*} \\
{[0.05]}\end{array}$ & $\begin{array}{c}0.91 \\
{[0.05]}\end{array}$ \\
\hline - Right & $\begin{array}{l}1.31^{* *} \\
{[0.07]}\end{array}$ & $\begin{array}{l}1.23 * * \\
{[0.07]}\end{array}$ & $\begin{array}{l}1.17^{* *} \\
{[0.06]}\end{array}$ & $\begin{array}{l}1.13^{*} \\
{[0.06]}\end{array}$ \\
\hline \multicolumn{5}{|l|}{ New cleavages: } \\
\hline Age & $\begin{array}{c}0.96 * * \\
{[0.01]}\end{array}$ & $\begin{array}{c}0.96^{* *} \\
{[0.01]}\end{array}$ & $\begin{array}{c}0.96^{* *} \\
{[0.01]}\end{array}$ & $\begin{array}{c}0.97^{* *} \\
{[0.01]}\end{array}$ \\
\hline $\mathrm{Age}^{\wedge} 2$ & $\begin{array}{l}1.00^{* *} \\
{[0.00]}\end{array}$ & $\begin{array}{l}1.00^{* *} \\
{[0.00]}\end{array}$ & $\begin{array}{l}1.00^{* *} \\
{[0.00]}\end{array}$ & $\begin{array}{l}1.00 * * \\
{[0.00]}\end{array}$ \\
\hline Female & $\begin{array}{l}0.85 * * \\
{[0.04]}\end{array}$ & $\begin{array}{l}0.87 * * \\
{[0.04]}\end{array}$ & $\begin{array}{c}0.86^{* *} \\
{[0.04]}\end{array}$ & $\begin{array}{l}0.77^{* *} \\
{[0.03]}\end{array}$ \\
\hline Primary education & ref. & ref. & ref. & ref. \\
\hline - Secondary education & $\begin{array}{c}1.05 \\
{[0.07]}\end{array}$ & $\begin{array}{l}1.15^{*} \\
{[0.08]}\end{array}$ & $\begin{array}{c}1.08 \\
{[0.07]}\end{array}$ & $\begin{array}{c}1.11 \\
{[0.07]}\end{array}$ \\
\hline - Tertiary education & $\begin{array}{l}1.23 * * \\
{[0.09]}\end{array}$ & $\begin{array}{l}1.46^{* *} \\
{[0.11]}\end{array}$ & $\begin{array}{l}1.20^{*} \\
{[0.09]}\end{array}$ & $\begin{array}{l}1.28^{* *} \\
{[0.09]}\end{array}$ \\
\hline Unemployed & $\begin{array}{c}1.15 \\
{[0.10]}\end{array}$ & $\begin{array}{c}1.06 \\
{[0.11]}\end{array}$ & $\begin{array}{c}1.11 \\
{[0.11]}\end{array}$ & $\begin{array}{c}0.94 \\
{[0.08]}\end{array}$ \\
\hline Retired & $\begin{array}{c}1.06 \\
{[0.08]}\end{array}$ & $\begin{array}{c}0.94 \\
{[0.07]}\end{array}$ & $\begin{array}{c}1.00 \\
{[0.07]}\end{array}$ & $\begin{array}{c}0.91 \\
{[0.06]}\end{array}$ \\
\hline Married & $\begin{array}{l}0.85 * * \\
{[0.05]}\end{array}$ & $\begin{array}{c}0.97 \\
{[0.06]}\end{array}$ & $\begin{array}{c}0.95 \\
{[0.06]}\end{array}$ & $\begin{array}{c}0.93 \\
{[0.05]}\end{array}$ \\
\hline Living in an urban area & $\begin{array}{l}1.15^{* *} \\
{[0.06]}\end{array}$ & $\begin{array}{l}1.16^{* *} \\
{[0.06]}\end{array}$ & $\begin{array}{l}1.11^{*} \\
{[0.05]}\end{array}$ & $\begin{array}{c}1.06 \\
{[0.05]}\end{array}$ \\
\hline 1-Pers. Household & ref. & ref. & ref. & ref. \\
\hline - 2-Person Household & $\begin{array}{c}1.05 \\
{[0.08]}\end{array}$ & $\begin{array}{c}0.95 \\
{[0.07]}\end{array}$ & $\begin{array}{c}0.99 \\
{[0.07]}\end{array}$ & $\begin{array}{c}0.98 \\
{[0.06]}\end{array}$ \\
\hline - >3-Person Household & $\begin{array}{c}1.04 \\
{[0.08]}\end{array}$ & $\begin{array}{c}0.88 \\
{[0.07]}\end{array}$ & $\begin{array}{c}0.93 \\
{[0.07]}\end{array}$ & $\begin{array}{c}0.90 \\
{[0.06]}\end{array}$ \\
\hline $\begin{array}{l}\text { Controlled for macro level } \\
\text { variables }\end{array}$ & Yes & Yes & Yes & Yes \\
\hline Median odds ratio & 1.37 & 1.54 & 1.56 & 1.51 \\
\hline Intra class correlation & 0.03 & 0.06 & 0.06 & 0.05 \\
\hline $\mathrm{N}$ & 14506 & 14300 & 13049 & 14238 \\
\hline
\end{tabular}

Note: ${ }^{*} p<0.05,{ }^{* *} p<.01$. Source: Own calculations, based on EEB61.1/EB64.2/EB66.3/EB71.3. 
Not surprisingly the direction of differences did not change over time - in all four years groups differ in their attitudes in the expected way. In a final step I now examine whether the strength of group differences has changed over time (Figure 11.2). I calculated net differences for the most relevant old and new cleavages in order to measure the intensity of conflict (Svallfors 2008). In 2004 the two old cleavages, social class and political ideology, are most pronounced. The predicted probability of accepting an increase of the retirement age for someone with a right political ideology is around 6 percentage points higher than for left-leaning individuals. While age, education and gender as new cleavages are less pronounced, they are still significantly different from zero. Over time the attitude structure remains rather stable. Social class, educational and age differences move in parallel, with social class remaining the most pronounced cleavage in the attitude structure. Nevertheless, we see some small changes with regard to political ideology and gender. Whereas in 2004 the differences between the political right and the left was the most distinct one, its intensity decreased steadily over time and is the least pronounced by 2009 . In contrast, the gender cleavage, while rather stable between 2004 and 2006, became more pronounced in 2009, which might be the result of the equalization trend of retirement age across genders. 


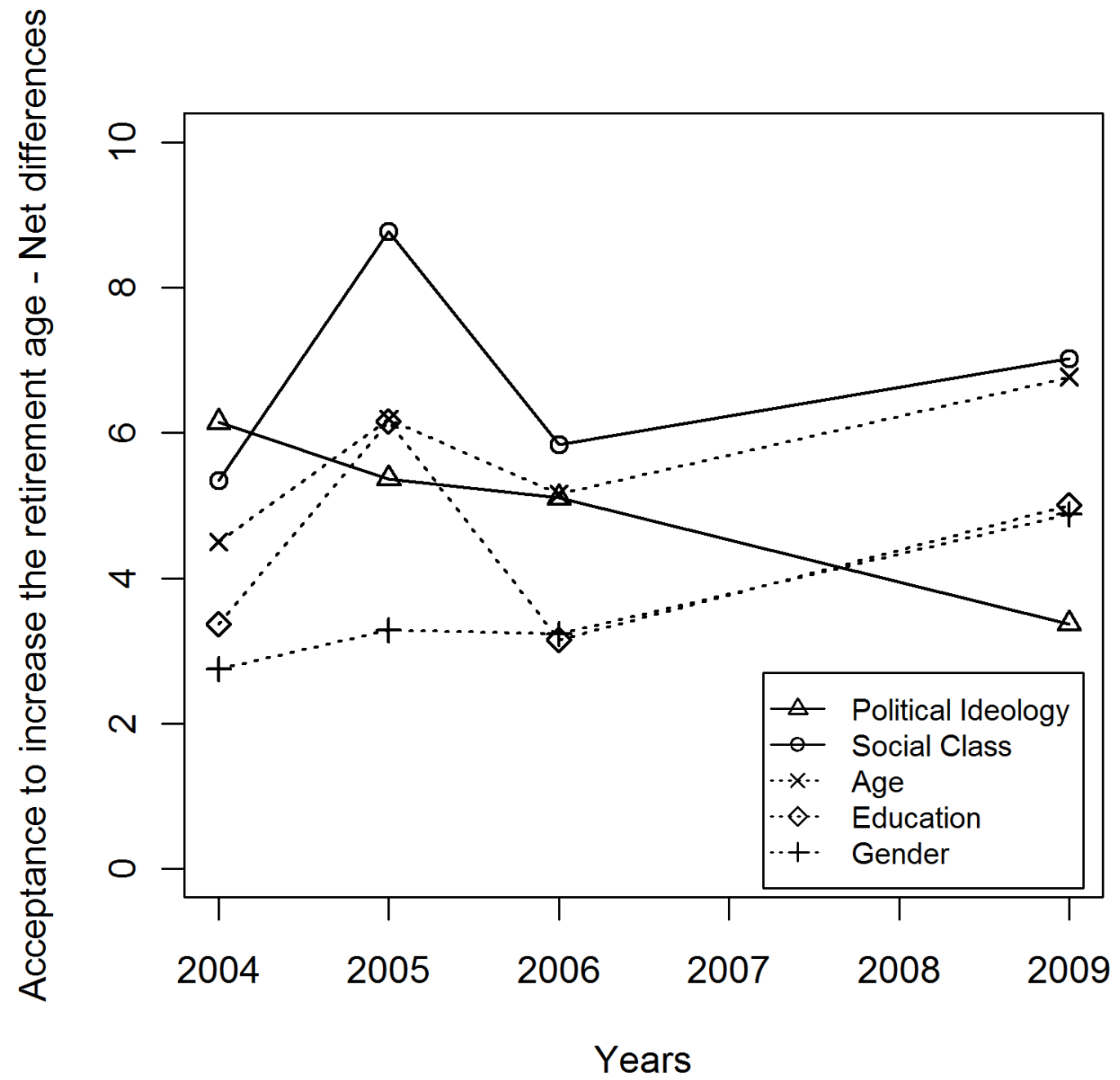

Note: Solid lines represent old cleavages, dotted lines represent new cleavages. A cleavage is measured as the net difference in the predicted probabilities of favouring an increase of the retirement age between the two most opposed groups controlling for all other variables included in the model. The most opposed groups are left versus right; highest social class $(\mathrm{ESeC} 1)$ versus lowest social class (ESeC4 and 5); the young (age $<=25)$ versus the old $(>64)$; people with tertiary education versus those with only primary education; and men versus women.

Figure 11.2 Old and new cleavages in preferences for increasing the retirement age in 25 EU countries between 2004 and 2009 


\section{CONCLUSION}

This chapter examined whether and to what extent changing economic and social conditions, growing reform pressures and, in particular, reforms (e.g. increasing the retirement age) influence citizens' preferences for reform alternatives aimed at preserving the pension system. While there is no lack of theoretical approaches explaining how welfare attitudes are formed with respect to changing economic, political and social contexts, empirical tests of these theories have tended to rely on cross-sectional data for a single point in time. This chapter sought to fill this gap by providing a dynamic approach that explores attitude change across different institutional settings. Moreover, previous research could only detect relationships between country contexts and attitudes (e.g. higher support for the welfare state in countries with high expenditures on welfare), but had difficulties establishing the causal direction of the relationship. Using time series analysis I tested the feedback effect of reforms on attitudes.

From 2004 to 2009 the preference for raising the retirement age increased in the 25 EU countries analysed in this study. Contrary to what most theories suggest (Pierson 2001), people seem to react to higher life expectancies and growing reform pressures by abandoning their reluctance to increase the retirement age. Public opinion might not always be the assumed major obstacle to welfare state retrenchment. Reforming the legal retirement age, however, changes preferences in the following year: Increasing the retirement age leads to a significant drop in acceptance of further raising the retirement age, thus supporting the saturation hypothesis. At first glance, the alignment hypothesis has to be rejected, as attitudes are neither in line with countries' institutional 
characteristics nor do they adapt to changes of the legal retirement age. However, the results of this study are clearly restricted to short-term effects, as the data only covers a very brief period of time. Previous research has shown that while alignment of attitudes to institutions exists, it works slowly, as it is mainly driven by generational replacement (Svallfors 2010). Taking different time horizons into account, both the saturation and the alignment hypotheses may be true. As shown in this chapter people change their attitudes against the reform direction in the short-run. In the long-run, however, this effect might be counterbalanced if people experience positive effects of a reform and adapt their absolute preferences to the new status quo. How a reform will affect attitudes in the long-run remains an open question - but also one which is possibly very challenging to answer. ${ }^{10}$

As for the pattern of attitudes within a country it is stability, and not change, that is observed. While both old and new cleavages are important determinants of the attitude structure, reforms do not affect these cleavage patterns since all groups within society (e.g. social classes or age groups) seem to move and adapt their attitudes in parallel over time. Nevertheless, there is some indication that gender differences have slightly increased in magnitude, possibly as a result of reforms aligning women's retirement ages to men's. Even such small and insignificant changes, when observed yearly, might add up over time and result in changed attitude patterns. Linking these conflict lines to the political opportunity structure of subsequent reforms, e.g. 'new' conflict lines cross-cutting 'old' political and/or class cleavages might create new possibilities for coalitions, would complete the circle, thereby going back to the determinants of policies and reflecting the idea of a dynamic policy process. 


\section{NOTES}

1. The 'Riester reform' reduced the replacement rate by about 10 per cent and introduced a voluntary, taxadvantaged funded pillar.

2. Another six countries (Belgium, Estonia, Hungary, Latvia, Lithuania and Slovenia) already enacted a reform in the late 1990s or early 2000s and are now in the phase of implementing these changes.

3. If currently not working the wording changed to: 'According to you, which of the following possibilities aimed at guaranteeing the financing of the pension system in (OUR COUNTRY), would be most acceptable for someone working?'

4. Around 10 per cent of respondents answered that they would favour a combination of all three policy alternatives, thus also accepting an increase in the retirement age. As their support for an increase in the retirement age might be much weaker, I did not group them together with the respondents accepting an increase in the retirement age in this study. Results are comparable for a different coding of the dependent variable.

5. The dependency ratio is an age-population ratio of those not in the labour force (age 65 and over) and those in the labour force (the productive part). It is used to measure the pressure on financing the pension system.

6. The aggregate replacement rate is defined as the ratio of the median individual gross pension of the $65-74$ age category relative to median individual gross earnings of the 50-59 age category, excluding other social benefits.

7. The difference-in-differences estimator is defined as follows: $\left(Y_{i, t_{1}}^{T}-Y_{i, t_{0}}^{C}\right)-\left(Y_{j, t_{1}}^{C}-Y_{j, t_{0}}^{C}\right), \mathrm{Y}$ is the average acceptance to work and contribute longer in country i at time $t$, where $t_{0}$ is the time before, $t_{1}$ the time after the reform, and $\mathrm{T}$ denotes the treatment (the reform). I assume that the difference between the treatment and control group should be the same before and after the treatment. If they are not the same, I ascribe the difference to the treatment.

8. Although increasingly popular to estimate the causal effect of an intervention or a reform, the difference-indifferences (DID) approach obviously has its limitations, like the endogeneity of the intervention itself or serial correlation (Heckman 2000). Results and standard errors presented here are quite robust to different specifications and econometric corrections (e.g. block bootstrap) as proposed by Bertrand et al. (2004)

9. As most coefficients changed only slightly after the inclusion of the new cleavages and the macro-indicators, I only present the four full models here. Results of the step-wise inclusion are available upon request.

10. Time lags of one year are common practice in the attitude research on short-term effects. But what is an agreed on time lag for long-term effects? And how could we deal with the idea of path dependence that long-term effects are the result of rather small and possibly insignificant cumulative effects over several years? 


\section{REFERENCES}

Angrist, J. and J.-S. Pischke (2009), Mostly Harmless Econometrics: An Empiricist's Companion, Princeton: Princeton University Press.

Arts, W. and J. Gelissen (2001), 'Welfare states, solidarity and justice principles: Does the type really matter?', Acta Sociologica, 44(4), 283-299.

Baumgartner, F. and B. Jones (2002), 'Positive and negative feedback in politics', Policy Dynamics, Chicago: University of Chicago Press.

Beck, U. (1992), Risk Society. Towards a New Modernity, London: Sage.

Beland, D. (2010), 'Reconsidering policy feedback: How policies affect politics', Administration \& Society, 42(5), 568-590.

Bertrand, M., E. Duflo and S. Mullainathan (2004), 'How much should we trust difference-in-differences estimates?', Quarterly Journal of Economics, 119(1), 249-275.

Boeri, T., A. Boersch-Supan and G. Tabellini (2002), 'Pension reforms and the opinions of European citizens', American Economic Review, 92(2), 396-401.

Brooks, C. and J. Manza (2006), 'Social policy responsiveness in developed democracies', American Sociological Review, 71(3), 474-494.

Burstein, P. (2003), 'The impact of public opinion on public policy: A review and an agenda', Political Research Quarterly, 56(1), 29-40.

Clark, T. and S. Lipset (eds) (2001), The Breakdown of Class Politics : A Debate on Post-Industrial Stratification, Baltimore: Johns Hopkins Univ. Press.

Ebbingahus, B. (2008), Reforming Early Retirement in Europe, Japan and the USA, Oxford: Oxford University Press.

Esping-Andersen, G. (1990), The Three Worlds of Welfare Capitalism, Princeton: Princeton University Press.

European Commission (2011a), 'eurostat', available at http://epp.eurostat.ec.europa.eu/portal/page/portal/statistics/search_database (accessed 17 January 2013). 
European Commission (2011b), 'Mutual Information System on Social Protection (MISSOC)', available at http://ec.europa.eu/employment_social/missoc/db/public/compareTables.do?lang=en (accessed 17 January 2013).

Fernández, J. and A. Jaime-Castillo (2013), 'Positive or negative policy feedbacks? Explaining popular attitudes towards pragmatic pension policy reforms', European Sociological Review, 29(4), 803815.

Fultz, E. (ed.) (2006), Pension Reform in the Baltic States, Budapest: International Labour Organization.

Hall, P. and R. Taylor (1996), 'Political science and the three new institutionalisms', Political Studies, 44(5), 936-957.

Heckman, J. (2000), 'Causal parameters and policy analysis in economics: A twentieth century retrospective', Quarterly Journal of Economics, 115(1), 45-97.

Hirose, K. (ed.) (2011), Pension Reform in Central and Eastern Europe: In Times of Crisis, Austerity and Beyond, Budapest: International Labour Organization.

Inglehart, R. (1990), Culture Shift in Advanced Industrial Society, Princeton: Princeton University Press.

Kahneman, D. and A. Tversky (1979), 'Prospect theory - analysis of decision under risk', Econometrica, 47(2), 263-291.

Korpi, W. (1983), The Democratic Class Struggle, London: Routledge.

Litwin, H., L. Achdut and I. Youssim (2009), 'Who supports delayed retirement? A study of older workeers in Israel', Journal of European Social Policy, 19, 245-257.

Lowi, T. (1964), 'American business, public policy, case-studies, and political theory', World Politics, 16(4), 677-715.

Lynch, J. and M. Myrskylä (2009), 'Always the third rail? Pension Income and policy preferences in European democracies', Comparative Political Studies, 42(8), 1068-1097.

Mettler, S. and J. Soss (2004), 'The consequences of public policy for democratic citizenship: Bridging policy studies and mass politics', Perspectives on Politics, 2(1), 55-73.

Naumann, E. (forthcoming), 'Increasing conflict in times of retrenchment? Attitudes towards healthcare provision in Europe between 1996 and 2002', International Journal of Social Welfare.

OECD (2011), Pensions at a Glance 2011: Retirement-income Systems in OECD and G20 Countries, OECD Publishing. 
Page, B. and R. Shapiro (1983), 'Effects of public-opinion on policy', American Political Science Review, 77(1), 175-190.

Pierson, P. (1993), 'When effect besomes cause - policy feedback and political change', World Politics, 45(4), 595-628.

Pierson, P. (2001), The New Politics of the Welfare State, Oxford: Oxford University Press.

Raven, J., P. Achterberg, R. VanDerVeen and M. Yerkes (2011), 'An institutional embeddedness of welfare opinions? The link between public opinion and social policy in the Netherlands (19702004)', Journal of Social Policy, 40(2), 1-18.

Rose, D. and E. Harrison (2007), 'The european socio-economic classification: A new social class schema for comparative European research', European Societies, 9(3), 459-490.

Soede, A. and C. Vrooman (2008), 'A comparative typology of pension regimes', ENEPRI Research Reports, 54.

Soroka, S. and C. Wlezien (2009), Degrees of Democracy: Politics, Public Opinion, and Policy, Cambridge: Cambridge University Press.

Svallfors, S. (2006), The Moral Economy of Class: Class and Attitudes in Comparative Perspective, Stanford: Stanford University Press.

Svallfors, S. (2008), 'The generational contract in Sweden: age-specific attitudes to age-related policies', Policy and Politics, 36(3), 381-396.

Svallfors, S. (2010), 'Policy feedback, generational replacement, and attitudes to state intervention: Eastern and Western Germany, 1990-2006', European Political Science Review, 2(1), 119-135.

Velladics, K., K. Henkens and H. Van Dalen (2006), 'Do different welfare states engender different policy preferences? Opinions on pension reforms in Eastern and Western Europe', Ageing \& Society, 26, 475-495.

Wlezien, C. (1995), 'The public as thermostat - dynamics of preferences for spending', American Journal of Political Science, 39(4), 981-1000. 